\title{
A Framework of Research and Practice: Relationship between Work Engagement, Affective Commitment, and Turnover Intentions
}

\author{
Liyu Zhao, Jingchao Zhao \\ School of Business Administration, South China University of Technology, Guangzhou, China \\ Email:645951165@qq.com
}

How to cite this paper: Zhao, L.Y. and Zhao, J.C. (2017) A Framework of Research and Practice: Relationship between Work Engagement, Affective Commitment, and Turnover Intentions. Open Journal of Social Sciences, 5, 225-233.

https://doi.org/10.4236/jss.2017.510019

Received: September 12, 2017

Accepted: October 28, 2017

Published: October 31, 2017

Copyright $\odot 2017$ by authors and Scientific Research Publishing Inc. This work is licensed under the Creative Commons Attribution International License (CC BY 4.0).

http://creativecommons.org/licenses/by/4.0/ (c) (i) Open Access

\begin{abstract}
There is a growing research interest in the topic of work engagement over the past years. In reference to Schauefeli, Salanova, Gonzalez-Roma \& Bakker (2002) [1], work engagement is described as "a positive, fulfilling work-related state of mind that is characterized by vigor, dedication and absorption". As compare to the researches based on the relationship between work engagement and organizational commitment and job performance, the existing researches on the relationship between work engagement and turnover intentions are far fewer. We theoretically discussed the relationship among work engagement, affective commitment and turnover intentions. Research results show that work engagement is negatively related to turnover intentions whereby affective commitment plays a regulating role. Affective commitment moderates the relationship between work engagement and turnover intentions whereby employees' affective commitment is stronger and employees are more willing to invest effort in their work; hence, employees' turnover intentions are reduced.
\end{abstract}

\section{Keywords}

Work Engagement, Affective Commitment, Turnover Intentions, Organizational Commitment

\section{Introduction}

Work engagement is a popular topic in the organizational literature. Previous studies have given several definitions for the term employee engagement. The term engagement is proposed in the Western Culture by Kahn (1990) [2]; it is 
defined as the process in which employees are physically, cognitively, and emotionally involved in their job roles. According to Harter, Schmidt \& Hayes (2002) [3], engagement is defined as something that the organizations want their employees to give $100 \%$ in all the domains such as productivity, creativity and innovation. In reference to Pandita \& Singhal (2017) [4], "employees" attitude makes a difference; engaged employees help the organization to retain customers, earn profits, enhance organizational culture and add to organization's goodwill."

Previous studies have showed that work engagement is positively related to life and job satisfaction (Hakanen \& Schaufeli, 2012 [5]; Saks, 2006 [6]), task performance (Bakker, Demerouti, \& Verbeke, 2004 [7]), and work ability (Airila, Hakanen, Punakallio, Lusa \& Luukkonen, 2012 [8]) and is negatively related to absenteeism (Schaufeli, Bakker, \& Van Rhenen, 2009 [9]) deviant behaviors (Shantz, Alfes, Truss, \& Soane, 2013 [10]; Sulea et al., 2012 [11]) and turnover intentions (Halbesleben, 2010 [12]). According to Shantz, Alfes \& Latham (2016) [13], the authors conducted a research from a manufacturing organization in UK on the relationship among work engagement, organizational commitment and turnover intentions; the result showed that a low level of work engagement was associated with a higher level of turnover intentions and deviance only when those employees did not perceived that they were supported by their organization. In reference to Schauefeli, Salanova, Gonzalez-Roma \& Bakker (2002) [1], work engagement is described as "a positive, fullfilling work-related state of mind that is characterized by vigor, dedication and absorptions." According to Schauefeli, Salanova, Gonzalez-Roma \& Bakker (2002) [1], the three dimensions of work engagement are defined as follows: 1) Vigor is "high level of energy and mental resilience while working, the willingness to invest effort in one's work and persistent even in the face of difficulties." 2) Dedication is "a sense of significance, inspirations, pride and challenge." 3) Absorption is "the state in which one is fully concentrated in his/her work; employees feel that time flies when working and have difficulties with detaching from working." In reference to Caesens, Stinglhamber \& Marmier (2016) [14], it states that if an organization provides valued resources to employees, it would foster the motivational process and the result would be that employees would be less inclined to leave their organization (Schaufeli \& Bakker, 2004 [15]).

Relatively to researches based on the relationship between work engagement and organizational commitment and job performance, the existing researches on the relationship between work engagement and turnover intentions are far fewer. The significance of this study is to help the organization management team to understand the present relationship between work engagement, affective commitment \&turnover intentions and think of necessary measures to increase employees' engagement, increase employees' affective commitment and decrease turnover intentions. In reference to the Social Exchange Theory (Blau, 1964) [16], social exchange is a process of negotiated exchange between parties. It implies a mutual benefit behavior and this kind of exchange has inconsistency and risks. According to Saks (2006) [6], engaged employees experience a reciproca- 
tion of favorable exchanges with the organization; likely have positive relationship with the employer; hence, likely to have intention to remain in the organization. The structure of this study consists of five parts which includes introduction, research method, research model and hypothesis development, framework of research and conclusion. This study focuses on the relationship among work engagement, affective commitment and turnover intentions.

\section{Method}

To achieve the objective of the study, we mainly use the literature research method. Using the literature research method to do the research refers to conduct the research by collecting identifying and reorganizing existing literature; come up with a scientific cognition of the research topic. The two aspects of the value of the literature research are as follows:

1) Through the literature research method, one can get new argument, new research perspective and new idea.

2) Through the literature research method, one can get revelation and evidence for his/her view from the previous researches.

In this study, we use the literature method to collect relative previous research results; and then come up with the idea that affective commitment as a moderating variable may influence the relationship between work engagement and turnover intentions. One of the obstacles in collecting relative literature is the amount of previous works that analysis the relationship between work engagement and turnover intentions are not that many.

\section{Research Model and Hypothesis Development}

\subsection{Work Engagement and Turnover Intentions}

How much effort are employees willing to invest in their work has been a concern for human resources in the organizations. According to Parker \& Griffin (2011) [17], the authors argued that low level of work engagement may not always lead to lower level of desirable work outcomes such as higher turnover intentions and deviant behaviors. Furthermore, the authors explained the reasons behind this phenomenon being that relatively disengaged employees may exhibit lower levels of turnover intentions and deviant behaviors due to other resources that are available in the work environment. Shantz, Alfes \& Latham (2016) [13], the result of the study suggested that "perceived organizational support moderates the relationship between work engagement and turnover intentions and deviant behaviors directed toward the organization; the perceived organizational support compensates for relatively low levels of work engagement. Scholars usually applied the Job demands resources model (JD-R) to explain employee burnout and work engagement (Bakker \& Demerouti; 2007 [18]; Demerouti, Bakker, Nachreiner \& Schaufeli, 2001 [19]; Hakanen, Bakker, \& Schaufeli, 2006 [20]). In reference to Shantz, Alfes \& Latham (2016) [13], the JD-R model comprises of two processes which are the health impairment process and the motiva- 
tional process. The health impairment process states that high job demands exhaust employees' mental and physical resources causing employee burnout and health problems. However, the motivational process predicts that job resources foster employee engagement, leading to positive attitudes and behaviors at work. According to Schaufeli \& Bakker (2004) [15], the term work engagement is referred as an active, positive, work-related state that consists of three dimensions which are vigor, dedication and absorption.

Lee, Chen, Wang \& Dadura (2010) [21], scholars have given intense attention to the subject of employee turnover due to the severity of employee turnover rates in various organizations across the globe and its damaging consequences. Mobley, Horner \&Hollingsworth (1978) [22], Turnover intentions is referred to be a conscious and deliberate willfulness to leave the organization. In reference to Tett \& Meyer (1993) [23], "It is often measured with reference to a specific interval (within the next 6 months), described as the last in a sequence of withdrawal cognition, a set to which thinking of quitting and intent to search for alternative employment also belong." Shantz, Alfes \& Latham (2016) [13], the authors conducted a research from a manufacturing organization in UK on the relationship among work engagement, organizational commitment and turnover intentions; the result showed that a low level of work engagement was associated with a higher level of turnover intentions and deviance only when those employees did not perceived that they were supported by their organization. In reference to Shantz, Alfes \& Latham (2016) [13], there is a need for research on the relationship between work engagement and less desirable outcomes for the organization such as turnover intentions and deviance. In reference to De Lange et al., (2008) [24], Employees may be hesitant to leave the job since work has provided so many resources such as flexibility, work-related skills to them. Halbesleben \& Wheeler (2008) [25], the authors argued that a highly engaged employee may find it difficult to detach from the job since he or she has invested so much energy and has high levels of identification with the job. According to Zhang, Ling \& Xie (2015) [26], the authors conducted a study of a sample of 512 building engineers in Taiwan, the results show that work engagement partially mediated the negative relationship between organizational commitment and turnover intention.

Vigor: Schauefeli, Salanova, Gonzalez-Roma \& Bakker (2002) [1], it is the aspect of work engagement which is defined as "high level of energy and mental resilence while working, the willingness to invest effort in one's work and persistent even in the face of difficulties." In reference to Schaufeli \& Bakker (2004) [15], it is difficult for engaged workers to detach from their work since they have invested so much energy into it. Halbesleben (2010) [12], engaged employees are unwilling to change jobs because they might consider it as a risky investment of time and effort. Based on the above analysis, we put forward the following hypothesis:

$H 1$ : If the vigor aspect of an employee's engagement is stronger, the turnover intention is lower. 
Dedication: Schauefeli, Salanova, Gonzalez-Roma \& Bakker (2002) [1], it is “a sense of significance, inspirations, pride and challenge." When an employee is dedicated to his/her job; according to Schaufeli \& Bakker (2004) [15], the experience of the engaged employees are described as a fulfilling positive work-related state of mind. Base on the above analysis, we put forward the following hypothesis:

H2: If the dedication aspect of an employee's engagement is stronger, the turnover intention is lower.

Absorption : Schauefeli, Salanova, Gonzalez-Roma \& Bakker (2002) [1], it is "the state in which one if fully concentrated in his/her work; employees feel that time flies when working and have difficulties with detaching from working." Schaufeli \& Bakker (2004) [15], "Being fully absorbed in one's work comes close to what has been called a "flow", a state of optimal experience that is characterized by focused attention, clear mind, mind and body union, effortless concentration, complete control, loss of self-consciousness, distortion of time and intrinsic enjoyment "(Csikszentmihalyi, 1990) [27]. Employees who are absorbed in their work go through positive experiences. Shantz, Alfes \& Latham (2016) [13], "these positive experiences and emotions act as energetic resources which leads to an employee's desire to remain in the organization"; hence, lower turnover intentions. Base on the above analysis, we put forward the following hypothesis:

H3: If the absorption aspect of an employee's engagement is stronger, the turnover intention is lower.

\subsection{The Moderating Role of Affective Commitment}

Allen \& Meyer (1990) [28], the three components of organizational commitment are: 1) Affective Commitment 2) Continuance Commitment 3) Normative Commitment. According to Wasti (2003) [29], the affective commitment is defined as employees' emotional attachment to, identification with and involvement in the organization. Continuance commitment refers to the high costs associated with leaving. Normative Commitment refers to employees' feelings of obligation to remain with the organization. In reference to Zhang, Ling, Zhang \& Xie (2015) [26], organizational commitment is defined as the psychological bond that individual has with the organization. According to Kim \& Kao (2014) [30] and Tett \& Meyer (1993) [23], Organizational commitment can directly reduce turnover intention. Zhang, Ling, Zhang \& Xie (2015) [26], the authors proposed work engagement as a mediator and person-supervisor fit as a moderator to find out the impact mechanism of organization commitment on turnover intention. Meyer, Stanley, Herscovitch \& Topolnytsky (2002) [31], affective commitment correlates with variables such as job satisfaction, job involvement and occupational commitment. The authors state that all three forms of organizational commitment are negatively related with withdrawal cognition, turnover intention and turnover; however, they are somewhat related to other work variable such as attendance, job performance and OCB differently. The authors also 
state that "the practical positive correlation between occupational commitment and affective commitment to the organization might have practical implication."

When the affective commitment of employees is stronger, employees' work engagement will be boosted up and employees will be more willing to invest effort in their work; hence, employees' intention to leave the organization will be lower. In this study, we use affective commitment as a moderating variable, we put forward the following hypothesis:

H4: Affective Commitment plays a regulatory role between the work engagement and turnover intentions.

\section{The Framework for Research}

Based on the analysis of the previous studies, we put forward the researching framework among work engagement, affective commitment and turnover intentions. As we can see in Figure 1, we propose the following four hypothesizes in the research: 1) If the vigor aspect of an employee's engagement is stronger, the turnover intention is lower. 2) If the dedication aspect of an employee's engagement is stronger, the turnover intention is lower. 3) If the absorption aspect of an employee's engagement is stronger, the turnover intention is lower. 4) Affective Commitment plays a regulatory role between the work engagement and turnover intentions.

\section{Conclusion}

Work engagement is "a positive, fulfilling work-related state of mind "(Schauefeli, Salanova, Gonzalez-Roma \& Bakker 2002) [1], which is related with positive experiences and behaviors and would reduce employees' intentions to leave the organization (Shantz, Alfes \& Latham, 2016) [13]. Relatively to researches based on the relationship between work engagement and organizational commitment and job performance, the existing researches on the relationship between work engagement and turnover intentions are far fewer. We mainly use the literature research method to conduct this research. Research results show that work engagement is negatively related to turnover intentions whereby affective commitment plays a regulating role. Affective commitment moderates the relationship

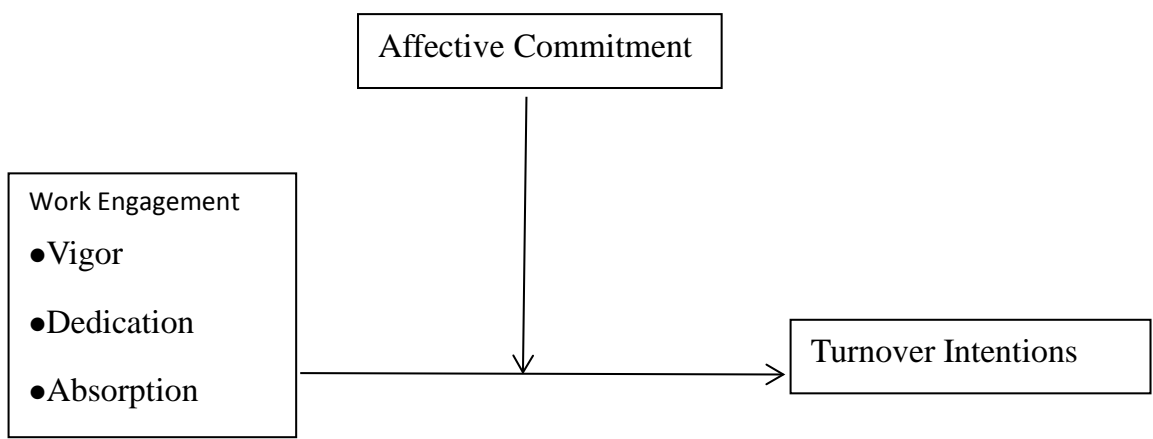

Figure 1. The researching framework among work engagement, affective commitment and turnover intentions. 
between work engagement and turnover intentions whereby employees' affective commitment is stronger and employees are more willing to invest effort in their work; hence, employees' turnover intentions are reduced. If all the proposed hypothesizes are true, human resources should observe employees' affective commitment; by increasing affective commitment. For example, human resources should organize activities to enhance the relationship between employees and the organization so as to build up employees' emotional attachment towards the organization. While promoting employees' affective commitment, it boosts employees' work engagement since it builds an emotional bond towards the organization-employees are more willing to invest effort and time which reduces employees' intentions to leave the organization. Although prior work has examined perceived organization support as the moderator between employee work engagement and turnover intentions and deviant behaviors (Shantz, Alfes, Latham 2016) [13], this study contributed to the work engagement literature by identifying a possible moderator affective commitment of the relationship between work engagement and turnover intention. The limitation of this paper is that this research only focuses on the literature research method. The limitation of using the literature research method is that the relative literature that are collected don't have a standardized format (the formats are different among papers); therefore, it could be challenging in the data coding or data organizing process. Future research can use other method such as the empirical research method to verify the hypothesizes.

\section{References}

[1] Schaufeli, W.B., Salanova, M., Gozale-Roma, V. and Bakker, A.B. (2002) The Measurement of Engagement and Burnout: A Two Sample Confirmatory Factor Analytic Approach. Journal of Happiness Studies, 3, 71-92. https://doi.org/10.1023/A:1015630930326

[2] Kahn, W.A. (1990) Psychological Conditions of Personal Engagement and Disengagement at Work. Academy of Management Journal, 33, 692-724. https://doi.org/10.2307/256287

[3] Harter, J.K., Schmidt, F.L. and Hayes, T.L. (2002) Business-Unit-Level Relationship between Employee Satisfaction, Employee Engagement, and Business Outcomes: A Meta-Analysis. Journal of Applied Psychology, 87, 268-279. https://doi.org/10.1037/0021-9010.87.2.268

[4] Pandita, S. and Singhal, R. (2017) The Influence of Employee Engagement on the Work-Life Balance of Employees in the IT Sector. The IUP Journal of Organizational Behavior, 16, 38-57.

[5] Hakanen, J.J. and Schaufeli, W.B. (2012) Do Burnout and Work Engagement Predict Depressive Symptoms and Life Satisfaction? A Three-Wave Seven-Year Prospective Study. Journal of Affective Disorders, 141, 415-424.

https://doi.org/10.1016/j.jad.2012.02.043

[6] Saks, A.M. (2006) Antecedents and Consequences of Employee Engagement. Journal of Managerial Psychology, 21, 600-619. https://doi.org/10.1108/02683940610690169

[7] Bakker, A., Demerouti, E. and Verbeke, W. (2004) Using the Job Demands-Resources 
Model to Predict Burnout and Performance. Human Resource Management, 43, 83-104. https://doi.org/10.1002/hrm.20004

[8] Airila, A., Hakanen, J., Punakallio, A., Lusa, S. and Luukkonen, R. (2012) Is Work Engagement Related to Work Ability beyond Working Conditions and Lifestyle Factors? International Archives of Occupational and Environmental Health, 85, 915-925. https://doi.org/10.1007/s00420-012-0732-1

[9] Schaufeli, W.B., Bakker, A.B. and Van Rhenen, W. (2009) How Changes in Job Demands and Resources Predict Burnout, Work Engagement, and Sickness Absenteeism. Journal of Organizational Behavior, 30, 893-917.

https://doi.org/10.1002/job.595

[10] Shantz, A., Alfes, K., Truss, C. and Soane, E.C. (2013) The Role of Employee Engagement in the Relationship between Job Design and Task Performance, Citizenship and Deviant Behaviors. International Journal of Human Resources Management (Early View Online), 24, 2608-2627. https://doi.org/10.1080/09585192.2012.744334

[11] Sulea, C., irga, D., Maricutoiu, L.P., Schaufeli, W., Dumitru, C.Z. and Sava, F.A. (2012) Work Engagement as Mediator between Job Characteristics and Positive and Negative Extra-Role Behaviors. Career Development International, 17, 188-207. https://doi.org/10.1108/13620431211241054

[12] Halbesleben, J.R.B. (2010) A Meta-Analysis of Work Engagement: Relationships with Burnout, Demands, Resources, and Consequences. In: Bakker, A.B. and Leiter, M.P., Eds., Work Engagement. A Handbook of Essential Theory and Research, Psychology Press, New York, 102-117.

[13] Shantz, A., Alfes, K. and Latham, G.P. (2016) The Buffering Effect of Perceived Organizational Support on the Relationship between Work Engagement and Behavioral Outcomes. Human Resources Management, 55, 25-38. https://doi.org/10.1002/hrm.21653

[14] Caesens, G., Stinglhamber, F. and Marmier, V. (2016) The Curvilinear Effect of Work Engagement on Employees' Turnover Intentions. International Journal of Psychology, 51, 150-155. https://doi.org/10.1002/ijop.12131

[15] Schaufeli, W.B. and Bakker, A.B. (2004) Job Demands, Job Resources and Their Relationship with Burnout and Engagement: A Multi-Sample Study. Journal of Organizational Behavior, 25, 293-315. https://doi.org/10.1002/job.248

[16] Blau, P.M. (1964) Exchange and Power in Social Life. Wiley, New York.

[17] Paker, S. and Griffin, M. (2011) Understanding Active Psychological States: Embedding Engagement in a Wider Nomological Net and Closer Attention to Performance. European Journal of Work and Organizational Psychology, 20, 60-67. https://doi.org/10.1080/1359432X.2010.532869

[18] Bakker, A.B. and Demerouti, E. (2007) The Job Demands-Resources Model: State of the Art. Journal of Managerial Psychology, 22, 309-328. https://doi.org/10.1108/02683940710733115

[19] Demerouti, E., Bakker, A.B., Nachreiner, F. and Schaufeli, W.B. (2001) The Job Demands-Resources Model of Burnout. Journal of Applied Psychology, 86, 499-512. https://doi.org/10.1037/0021-9010.86.3.499

[20] Hakanen, J.J., Bakker, A.B. and Schaufeli, W.B. (2006) Burnout and Work Engagement among Teachers. Journal of School Psychology, 43, 495-513.

[21] Lee, T.-R., Chen, S.-Y., Wang, S.-H. and Dadura, A. (2010) The Relationship between Spiritual Management and Determinants of Turnover Intention. European Business Review, 22, 102-116. https://doi.org/10.1108/09555341011009034 
[22] Mobley, W.H., Homer, S.O. and Hollingsworth, A.T. (1978) An Evaluation of Precursors of Employee Turnover. Journal of Applied Psychology, 63, 408-414. https://doi.org/10.1037/0021-9010.63.4.408

[23] Tett, R.P. and Meyer, J.P. (1993) Job Satisfaction, Organizational Commitment, Turnover Intention, and Turnover: Path Analyses Based on Meta-Analytic Findings. Personal Psychology, 46, 259-293. https://doi.org/10.1111/j.1744-6570.1993.tb00874.x

[24] De Lange, A.H., De Witte, H. and Notelaers, G. (2008) Should I Stay or Should I Go? Examing Longitudinal Relations among Job Resources and Work Engagement for Stayers versus Movers. Work and Stress, 22, 201-223. https://doi.org/10.1080/02678370802390132

[25] Halbesleben, J.R.B. and Wheeler, A.R. (2008) The Relative Roles of Engagement and Embeddedness in Predicting Job Performance and Intention to Leave. Work and Stress, 22, 242-256. https://doi.org/10.1080/02678370802383962

[26] Zhang, J.C., Ling, W.Q., Zhang, Z.Y. and Xie, J. (2015) Organizational Commitment, Work Engagement, Person-Supervisor Fit, and Turnover Intention: A Total Effect Moderation Model. Social Behavior and Personality, 43, 1657-1666. https://doi.org/10.2224/sbp.2015.43.10.1657

[27] Csikszentmihalyi, M. (1990) Flow: The Psychology of Optimal Experience. Harper, New York.

[28] Allen, N.J. and Meyer, J.P. (1990) The Measurement and Antecedents of Affective, Continuance, and Normative Commitment to the Organization. Journal of Occupational Psychology, 63, 1-18. https://doi.org/10.1111/j.2044-8325.1990.tb00506.x

[29] Wasti, S.A. (2003) Organizational Commitment, Turnover Intentions, and the Influence of Cultural Values. Journal of Occupational and Organizational Psychology, 76, 303-321. https://doi.org/10.1348/096317903769647193

[30] Kim, H. and Kao, D. (2014) A Meta-Analysis of Turnover Intention Predictors among U.S. Child Welfare Workers. Children and Youth Services Review, 47, 214-223.

[31] Meyer, J.P., Stanley, D.J., Herscovitch, L. and Topolntsky, L. (2002) Affective, Continuance, and Normative Commitment to the Organization: A Meta-Analysis of Antecedents, Correlates and Consequences. Journal of Vocational Behavior, 61, 20-52. https://doi.org/10.1006/jvbe.2001.1842 